\title{
PENGERTIAN KOMUNIKASI, MANFAAT, DAN URGENSINYA
}

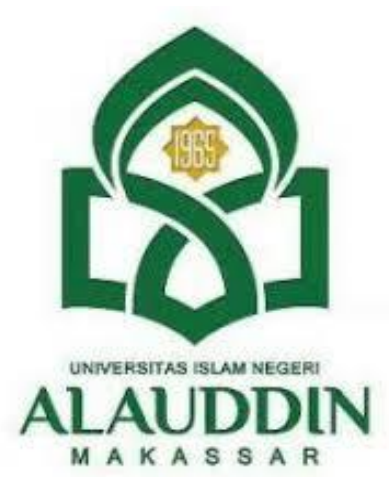

MAKALAH

Dipresentasikan pada Mata Kuliah Sistem Komunikasi Bisnis Program Studi Perbankan Syariah Semester VTahun 2021

OLEH :

KELOMPOK 1

1. Warda (90500119077)

2. Amelia Ananda Bahru (90500119055)

3. Fitri Ramdani (90500119048)

Dosen Pengampu : Dr. Siti Fatimah, S.E.,M.M.

PROGRAM STUDI PERBANKAN SYARIAH

FAKULTAS EKONOMI DAN BISNIS ISLAM UIN ALAUDDIN MAKASSAR 


\section{KATA PENGANTAR}

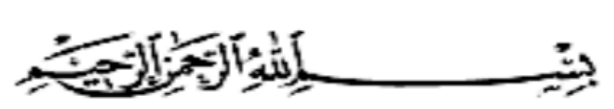

Puji syukur kehadirat Allah SWT atas rahmat, hidayah, dan karunia-Nya kepada penyusun sehingga dapat disusun makalah Sistem Komunikasi Bisnis Perbankan Syariah yang berjudul "Pengertian Komunikasi, Manfaat, dan

\section{Urgensinya".}

Tidak lupa saya ucapkan terima kasih kepada semua pihak yang telah membantu, memberi saya petunjuk dan arahan selama penulisan makalah ini.

Penyusun memahami bahwa makalah ini masih belum lengkap, sehingga penyusun mengharapkan kritik dan saran yang sangat membangun untuk melengkapi makalah ini.

Akhir kata penyusun meminta maaf karena banyak melakukan kesalahan dalam pengeditan makalah ini. Kami berharap makalah ini akan sangat membantu bagi penyusun dan pembaca umum.

Makassar, 12 September 2021

Penyusun

Kelompok 1 


\section{DAFTAR ISI}

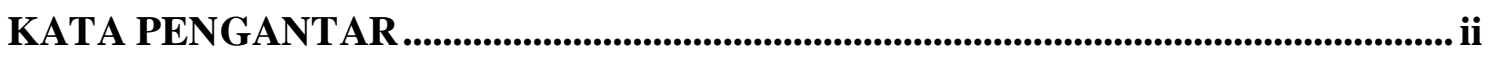

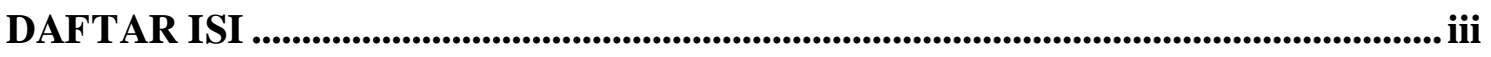

\section{BAB I}

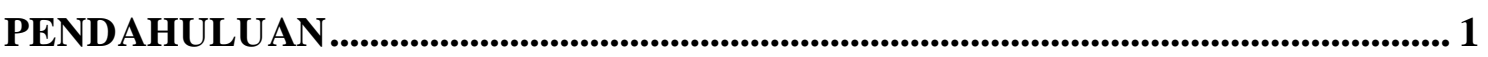

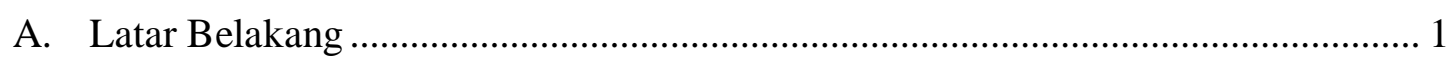

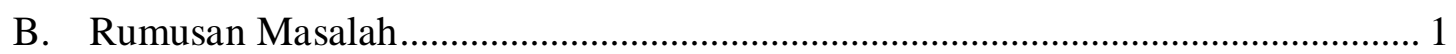

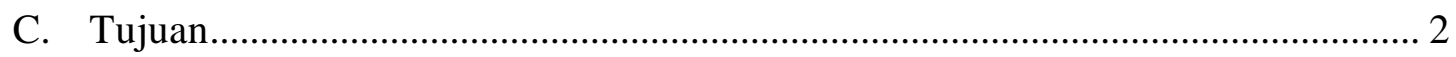

\section{BAB II}

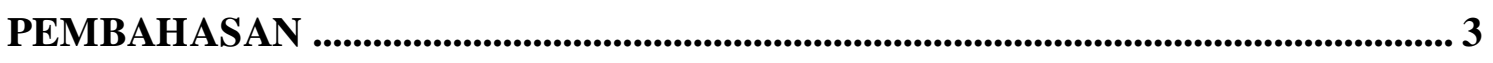

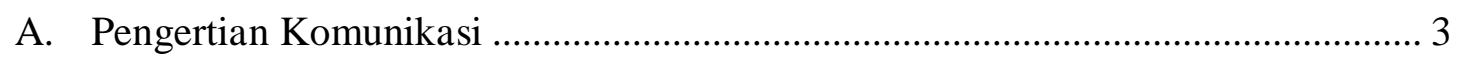

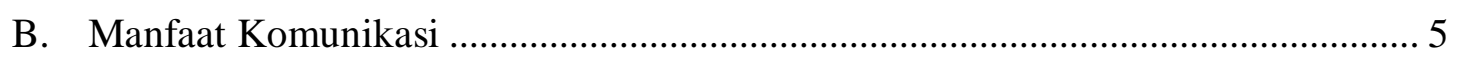

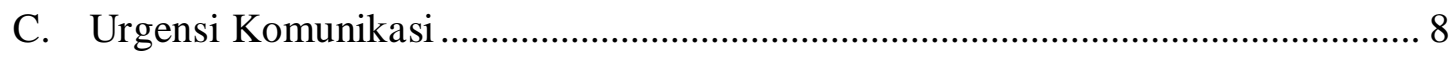

\section{BAB III}

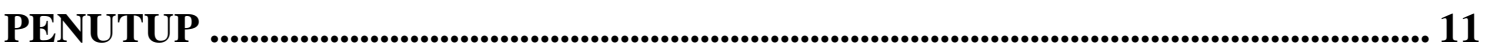

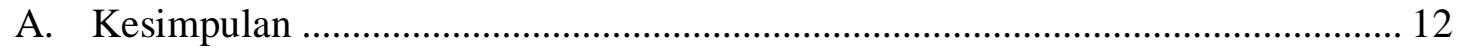

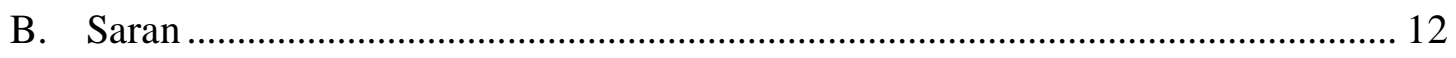

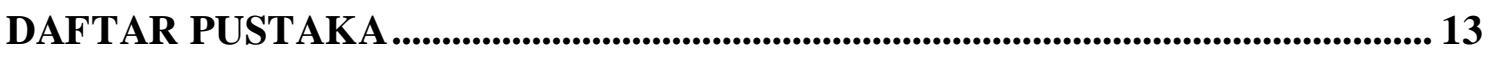




\section{BAB I \\ PENDAHULUAN}

\section{A. Latar Belakang}

Sebagai makhluk sosial, manusia berada pada kedudukan yang lebih baik dan lebih mulia. Ini karena manusia diberkahi dengan karunia berbicara. Sebagaimana dipahami dalam Surah Ar-Rahman (55:4), manusia dapat membangun interaksi sosial dengan kemampuan berbicara. Ayat ini dijelaskan oleh Quraysh Shihab dalam tafsir AlMishba. Potensi Albayan yang melekat pada manusia memungkinkan manusia untuk hidup bersama dalam kehidupan sosial. Dan suara dapat memiliki makna yang disepakati bersama, dan dengan demikian, pada gilirannya menciptakan hubungan yang saling berinteraksi untuk menciptakan komunitas kehidupan sosial. ${ }^{1}$ Dia juga menjelaskan bahwa perkembangan kehidupan masyarakat yang luar biasa saat ini adalah ekspresi percakapan, potensi pekerja paruh waktu untuk membuka pintu untuk memahami dan menerima orang.

Berbicara berarti mampu berkomunikasi. Komunikasi dalam kehidupan manusia tidak dapat dipisahkan dari keberadaan. Komunikasi membangun interaksi dalam kehidupan sehari-hari, dan kehadiran komunikasi menjadikan kehidupan dalam suatu komunitas bermakna, baik formal maupun informal.

Komunikasi ada di mana-mana, kapan saja, di mana saja dengan siapa saja. Ya, itu adalah aktivitas yang paling banyak dilakukan orang dan tidak bisa dihindari dalam kehidupan kita sehari-hari. Kehidupan modern memungkinkan setiap orang untuk berkomunikasi di mana saja. ${ }^{2}$

\section{B. Rumusan Masalah}

1. Apakah yang dimaksud dengan komunikasi?

2. Apa sajakah manfaat dari komunikasi?

3. Bagaimanakah urgensi komunikasi?

\footnotetext{
Hati, 2003)

${ }^{1}$ M. Quraish Shihab, Tafsir Al-Misbah: Pesan Dan Kesan Dalam Al-Quran (Jakarta: Lentera

${ }_{2}^{2}$ Ahmad Sultra Rustan dan Nurhakki Hakki, Pengantar Ilmu Komunikasi, ed. by Deepublish (Yogyakarta, 2017).
} 


\section{Tujuan}

1. Dapat mengetahui definisi dari komunikasi baik secara umum maupun dari sudut pandang Islam.

2. Dapat mengetahui manfaat dari suatu komunikasi yang baik.

3. Dapat mengetahui urgensi komunikasi dalam kehidupan sehari-hari. 


\section{BAB II \\ PEMBAHASAN}

\section{A. Pengertian Komunikasi}

\section{Menurut Bahasa}

Kata komunikasi berasal dari 'communis' yang berarti 'mendekatkan' atau 'membangun persatuan' antara dua orang atau lebih. ${ }^{3}$

Dalam Kamus Umum Bahasa Indonesia mengatakan bahwa komunikasi adalah hubungan komunikatif, garis, alat komunikasi, berita pemberitahuan dsb. ${ }^{4}$

Berdasarkan penjelasan tersebut, dapat disimpulkan bahwa komunikasi adalah suatu kesatuan atau hubungan satu sama lain. Jadi, ketika dua orang atau sekelompok orang melakukan komunikasi, misalnya dalam bentuk percakapan, komunikasi terjadi atau berlanjut selama ada kesamaan makna dari apa yang dikatakan. ${ }^{5}$

\section{Menurut Istilah}

Berbicara tentang komunikasi, ada beberapa argumentasi dari beberapa ahli, antara lain:

a. Menurut Everet M. Rogers:

"Komunikasi adalah proses dimana ide-ide ditransmisikan dari sumber ke satu atau lebih penerima untuk mengubah perilaku."6

b. Laswell mengemukakan:

Komunikasi mencakup lima elemen: komunikator, pesan, media, komunikasi, dan efek. $^{7}$

c. Menurut Hoveland bahwa:

\footnotetext{
${ }^{3}$ John M. Echols dan Hasan Sadily, Kamus Inggris Indonesia (Jakarta: Gramedia, 1993).

${ }^{4}$ Departemen Pendidikan dan Kebudayaan RI, Kamus Besar Bahasa Indonesia (Jakarta: Balai Pustaka, 1990).

${ }^{5}$ Muhammad Haramain, Prinsip-Prinsip Komunikasi Dalam Al-Qur 'an (Pare-Pare: IAIN Parepare Nusantara Press, 2019).

${ }^{6}$ Hafied Cangara, Pengantar Ilmu Komunikasi (Jakarta: Raja Grafindo Persada, 1998). Rosdakarya, 1990).
} 
"Komunikasi adalah proses dimana komunikator mengubah perilaku orang lain dengan mengirimkan stimulus, biasanya simbol dalam bentuk kata-kata yang mengubah tingkah laku orang lain."

\section{Komunikasi Islam}

Dari beberapa konsep komunikasi sebelumnya, terlihat bahwa komunikasi dalam Islam adalah proses penyampaian pesan dengan menggunakan prinsip-prinsip Islam dalam Pesan dan Cara Penyampaiannya. Pedoman pertama dan terpenting adalah Al-Qur'an, yang menetapkan prinsip-prinsip dasar Islam dan meletakkan dasar bagi tindakan Islam. Buku pegangan kedua menjelaskan, mengartikulasikan dan menghubungkan prinsip-prinsip ini dengan kehidupan nyata masyarakat dalam perbuatan, kata-kata dan sifat Sunnah atau Persetujuan Nabi (SAW). ${ }^{9}$

Berdasarkan keterangan Al-Qur'an dan As-Sunnah, telah terungkap bahwa komunikasi Islami adalah komunikasi yang bertujuan untuk membangun hubungan dengan Sang Pencipta dan sesama dalam rangka mewujudkan kedamaian, keramahtamahan dan keselamatan diri sendiri dan lingkungan dengan mentaati perintah. Allah dan Rasul-Nya. Setiap tindakan komunikasi yang menyebabkan sakit hati, sakit atau luka pada hati orang lain bertentangan dengan komunikasi Islam.

Dari sudut pandang Islam, komunikasi melibatkan selain membangun hubungan vertikal dengan Allah, Pencipta alam semesta. Ia juga menjalin komunikasi horizontal dengan orang lain. Komunikasi dengan Allah diwujudkan melalui ibadah wajib, yaitu shalat, puasa, zakat dan haji, yang tujuannya adalah untuk membentuk taqwa. Sedangkan komunikasi dengan orang lain menitikberatkan pada hubungan sosial yang disebut muamala, yang tercermin dalam semua aspek kehidupan manusia, termasuk masyarakat, budaya, politik, ekonomi, dan seni. ${ }^{10}$

Dalam berbagai literatur tentang komunikasi Islam setidaknya kita dapat menemukan 6 jenis tuturan atau kaulan, yang tergolong kaidah, prinsip atau etika komunikasi Islam, yaitu :

\footnotetext{
${ }^{8}$ H. Anwar Arifin, Ilmu Komunikasi Sebuah Pengantar Ringkas (Jakarta: Rajawali Press, 1992).

${ }^{9}$ Muhamad Bisri Mustofa, Siti Wuryan, and Rosidi, 'Urgensi Komunikasi Interpersonal Dalam Al-Qur'an Sebagai Pustakawan', AL-HIKMAH: Media Dakwah, Komunikasi, Sosial Dan Budaya, 11.2 (2020), 85-94 <https://doi.org/10.32505/hikmah.v11i2.2544>. 16.

${ }^{10}$ Nazarullah, ‘Teori-Teori Komunikasi Massa Dalam Perspektif Islam', Peurawi, 1.1 (2018), 1 -
} 


\section{a. Qaulan Sadida}

Qaulan Sadidan berarti kata, kata atau kata yang benar baik isi (materi, isi, pesan) maupun redaksionalnya (tata bahasa).

\section{b. Qaulan Baligha}

Kata balig berarti tepat, sederhana, bebas dan jelas maknanya. Qaulan Baligha berarti menggunakan kata-kata komunikatif yang efektif dan terarah, mudah dipahami dan langsung pada intinya tanpa rumit dan bertele-tele.

\section{c. Qaulan Ma'ufa}

Kata Qaulan Ma`rufan disebutkan Allah dalam QS An-Nissa :5 dan 8, QS. Al-Baqarah:235 dan 263, serta Al-Ahzab: 32.

Qaulan Marufa artinya kata-kata yang baik, ungkapan yang tepat, kesopanan, dan menggunakan sarkasme (bukan kekasaran), bukan hinaan atau hinaan. Kaulan ma'rufa juga berarti perkataan yang bajik dan membawa kebaikan (maslahat).

\section{d. Qaulan Karima}

Qaulan Karima adalah kata yang mulia disertai rasa hormat dan luhur, enak didengar, lemah lembut dan santun. Kata-kata mulia dalam ayat ini harus ditujukan kepada kedua orang tua. Kita tidak boleh menegur mereka atau mengatakan apa pun yang menyinggung perasaan mereka.

\section{e. Qaulan Layina}

Kata-kata Kaulan Layina yaitu kata yang lembut, suaranya yang merdu, dan penuh keramahan yang berarti dapat menyentuh hati.

\section{f. Qaulan Maysura}

Qaulan Maysura berarti pidato yang mudah dipelajari, mudah dipahami, dan mudah dipahami lawan bicara Anda. Arti lainnya termasuk kata-kata yang menyenangkan atau hal-hal yang menyenangkan. ${ }^{11}$

\section{B. Manfaat Komunikasi}

Gambar komunikasi yang berbeda juga memberikan perspektif yang berbeda tentang fungsi komunikasi. Komunikasi dapat memuaskan hidup kita ketika semua kebutuhan fisik, identitas, sosial dan kebutuhan praktis terpenuhi.

Ada beberapa fungsi komunikasi:

11 Romeltea, 'Komunikasi Islam: Pengertian Dan Prinsip', 1 Juni, 2020 <https://romeltea.com/komunikasi-islam-makna-dan-prinsip/> [accessed 22 December 2021]. 
1. Fungsi Regulatif

2. Fungsi Integrative

3. Fungsi Persuasif

4. Fungsi Informatif

Menurut para ahli, fungsi komunikasi antara lain:

1. Thomas M. Scheidel. Menurutnya, orang umumnya berkomunikasi melalui komunikasi untuk mengekspresikan dan mendukung identitas mereka, untuk membangun interaksi sosial dengan orang-orang di sekitar mereka, dan untuk mempengaruhi orang lain untuk berpikir, merasa, atau berperilaku seperti yang diharapkan.

2. Rudolph F. Werderber. Menurutnya, komunikasi memiliki fungsi: fungsi sosial dan fungsi pengambilan keputusan. Fungsi sosial mereka semua untuk bersenangsenang, untuk menunjukkan koneksi, dan untuk membangun dan memelihara hubungan dengan orang lain. Kemampuan membuat keputusan adalah memutuskan apakah akan melakukan sesuatu pada waktu tertentu atau tidak.

3. Gordon I. Zimmerman menjelaskan bahwa komunikasi membantu kita untuk menikmati hidup serta menyediakan makanan dan pakaian, memuaskan rasa ingin tahu kita tentang lingkungan, serta tugas-tugas penting yang kita butuhkan. Selain itu, hal terpenting dalam komunikasi adalah menciptakan dan mengembangkan hubungan dengan orang-orang di sekitar Anda. ${ }^{12}$

Keunggulan komunikasi dalam Islam sendiri adalah keberadaan komunikasi Islam bertujuan untuk membimbing umat Islam dan masyarakat awam untuk berkomunikasi dengan Penciptanya dan sesama sesuai dengan prinsip-prinsip Islam. Komunikasi dengan pemimpin agama akan mengikuti jalan yang telah ditentukan oleh Allah SWT.

Komunikasi berdasarkan prinsip-prinsip komunikasi Islam akan membawa kedamaian dan keamanan bagi komunikator dan masyarakat secara keseluruhan. Jika Muslim berkomunikasi dengan orang lain dengan niat serius untuk membangun persahabatan dan meningkatkan kualitas hubungan positif, mereka tidak hanya akan mendapat manfaat dari dunia ini, tetapi juga akan menerima imbalan di masa depan. ${ }^{13}$

Oleh karena itu, komunikasi dan masyarakat adalah dua kata yang tidak dapat

\footnotetext{
${ }^{12}$ Hafied Cangara, Pengantar Ilmu Komunikasi (Jakarta: PT. Raja Grafindo Persada, 2008).

${ }^{13}$ Dr. Harjani Hefni, Komunikasi Islam (Jakarta: Kencana, 2015).
} 
dipisahkan. Pembentukan masyarakat tidak mungkin tanpa komunikasi, dan sebaliknya, komunikasi tidak dapat berkembang tanpa masyarakat.

Dalam dunia kerja, komunikasi yang baik diperlukan karena alasan berikut:

1. Hirarki manajemen datar

2. Manajemen yang lebih partisipatif

3. Manajemen berbasis tim tingkat lanjut

4. Persaingan global yang tinggi

5. Teknologi komunikasi yang inovatif

6. Lingkungan kerja baru

7. berfokus pada informasi sebagai nilai perusahaan

Jenis Komunikasi :

1. Komunikasi antarpribadi

2. Komunikasi kelompok

3. Media

4. Komunikasi organisasi

5. Komunikasi politik

6. Komunikasi antara budaya

Gaya komunikasi

1. Kontrol gaya (batasan, pengaturan)

2. Gaya egaliter

3. Gaya terstruktur

4. Gaya dinamis

5. Menyerah gaya

6. Jenis pembayaran

Prosa Komunikasi

1. Sumber keuangan

2. Pesan

3. Media

4. Penerima informasi

5. Umpan Balik

6. Gangguan atau kebisingan

Hambatan komunikasi 
1. Salah mengenali

2. Pesannya tidak jelas

3. Tanggapan manajemen

4. Semantik

5. Komunikasi informal

6. Kerusakan media

\section{Urgensi Komunikasi}

Komunikasi merupakan salah satu aspek dari hubungan interpersonal yang baik. Tanpa komunikasi, sulit untuk menghindari kerentanan interaksi manusia. Oleh karena itu, yang kita butuhkan dalam hidup ini adalah komunikasi. Dan menciptakan komunikasi yang berkualitas sangat penting.

Menurut Profesor Deddi Mulyana, Pentingnya Riset Komunikasi, dengan berkembangnya peradaban dan kemajuan teknologi umat manusia, ilmu komunikasi semakin mendapat tempat yang penting dalam pengembangan dan penelitiannya. Komunikasi sebagai sebuah teknologi. ${ }^{14}$

Pertama, komunikasi sebagai ilmu yang mengajarkan pengetahuan dan keterampilan di berbagai bidang seperti jurnalis, humas, pakar manajemen komunikasi, politisi, ilmuwan, cendekiawan, diplomat, serta presenter radio dan televisi. Selain itu, ilmu komunikasi akan dipelajari lebih luas sekarang dan di masa depan dan, jika perlu, berkontribusi pada munculnya spesifikasi pembelajaran, sehingga berkontribusi pada pengembangan komunikasi kriminal, situasi krisis, hukum, digital, (Al-Qur'an, undang-undang, pendidikan).

Kedua, karena fenomena komunikasi ada di semua lapisan dan semua bidang kehidupan sosial manusia, maka ia merupakan studi yang dapat mempelajari berbagai masalah sosial yang terjadi dalam masyarakat, yaitu komunikasi sebagai bidang ilmu. Di Indonesia, dalam konteks kehidupan sosial yang sangat heterogen dan pluralistik, perlu dibangun epistemologi konstruktif yang mencari kebaruan, karena masih dijiwai oleh model sosial tradisional kearifan lokal, modal sosial masyarakat. Kami membangun teori kontekstual dan orisinal atau teori baru berdasarkan praktik komunikasi yang ada di masyarakat kita.

14 Dedy Mulyana, Mau Kemana Ilmu Komunikasi Kita. Ilmu Komunikasi Sekarang Dan Tantangan Masa Depan (Jakarta: Kencana, 2013). 
Ketiga, komunikasi sebagai teknologi. Keterampilan komunikasi atau communication ability mengacu pada kemampuan berkomunikasi secara efektif. ${ }^{15}$ Kompetensi ini mencakup pengetahuan tentang peran lingkungan (konteks) dalam mempengaruhi isi atau isi dan format pesan komunikasi. Di era mobilitas tinggi, orang bergerak dalam lingkungan komunikasi yang berbeda, sehingga keterampilan komunikasi memainkan peran penting dalam meningkatkan pencapaian pribadi dan mencapai keharmonisan dalam kehidupan sosial di lembaga pengembangan karir. Meskipun keterampilan komunikasi bukan satu-satunya obat mujarab untuk pemecahan masalah, sebuah studi oleh University of Michigan menemukan bahwa faktor yang menentukan keberhasilan individu dalam suatu organisasi termasuk keterampilan komunikasi lisan dan tertulis, keterampilan kepemimpinan, keterampilan analitis, kerja tim, dan keterampilan komunikasi. Kelola perubahan, kepekaan sosial dan profesional, serta manajemen keuangan.

Secara umum, orang yang pandai berbicara dianggap dapat dipercaya dan oleh karena itu lebih mungkin untuk berhasil dalam karier mereka. Orang dengan keterampilan komunikasi akan dijadikan pemimpin karena dapat memberikan arahan, memotivasi, menyelesaikan konflik, membangun kohesi tim, dan menciptakan iklim dan budaya organisasi yang ditandai dengan hubungan interpersonal yang baik.

Ilmu komunikasi sangat penting untuk dipelajari karena proses komunikasi merupakan proses yang sangat kompleks. Dibutuhkan pelatihan untuk dapat menggunakan dan menganalisisnya secara efektif. Karena "kita tidak punya pilihan selain berkomunikasi". Komunikasi adalah kegiatan yang merasuki kehidupan kita saat ini dan menentukan kualitas hidup kita sebagai individu, keluarga, profesional dan anggota masyarakat. Setiap orang dilahirkan dengan potensi komunikatif, atau biasa disebut talenta, tetapi bakat itu harus diubah menjadi keterampilan melalui pelatihan. Tidak semua keterampilan yang dapat dipelajari dalam hidup adalah hasil belajar dan latihan yang tidak kenal lelah, seperti mengendarai sepeda motor atau mengendarai mobil, dan beberapa kesalahan yang dapat menyebabkan cedera selama latihan, tetapi pada akhirnya bergerak dengan lancar di jalan raya tanpa mengganggu pengemudi. tidak melihat.

\section{Urgensi Komunikasi dalam Organisasi}

15 Agus Maulana Joseph A. Devito, Komunikasi Antar Manusia (Jakarta: Karisma Publishing Group, 2011). 
Pentingnya komunikasi dalam sebuah organisasi dapat diringkas sebagai berikut:

a. Komunikasi meningkatkan motivasi dengan menginformasikan dan mendidik karyawan tentang apa yang perlu dilakukan, bagaimana melakukannya, dan bagaimana meningkatkan kinerja bila kurang.

b. Dalam pengambilan keputusan, ini berfungsi sebagai sumber informasi bagi anggota organisasi untuk mengomunikasikan proses pengambilan keputusan, dan untuk membantu mengidentifikasi dan mengevaluasi prosedur alternatif.

c. Komunikasi juga memainkan peran penting dalam mengubah sikap individu. Dengan kata lain, orang yang kaya informasi memiliki akses yang lebih baik daripada orang yang tidak kaya pengetahuan. Majalah perusahaan, jurnal, konferensi, dan berbagai bentuk komunikasi lisan dan tertulis membantu membentuk sikap karyawan.

d. Komunikasi juga membantu masyarakat. Dalam kehidupan saat ini, komunikasi difasilitasi hanya dengan kehadiran orang lain. Mereka juga mengatakan bahwa tanpa komunikasi tidak akan ada eksistensi..

e. Komunikasi juga membantu mengelola proses. Ada berbagai tingkat hierarki dan prinsip serta pedoman khusus yang harus dipatuhi oleh karyawan dalam organisasi. Mereka diharapkan untuk mengikuti aturan, menjalankan tugasnya secara efektif, dan melaporkan kekhawatiran dan keluhan mereka kepada atasan mereka. Oleh karena itu, komunikasi membantu dalam menjalankan fungsi administratif.

Sistem komunikasi yang efisien dan efektif membutuhkan keterampilan manajemen untuk mengirim dan menerima pesan. Manajer harus mengidentifikasi berbagai hambatan komunikasi, menganalisis penyebabnya, dan mengambil tindakan untuk menghindari hambatan tersebut. Oleh karena itu, tanggung jawab utama manajer adalah mengembangkan dan memelihara sistem komunikasi yang efektif dalam organisasi mereka.

\section{Urgensi Komunikasi di Era Pandemi Covid-19}

Komunikasi yang efektif selama pandemi COVID-19 sangat penting, dan informasi dengan kata-kata dan ekspresi yang saling menguatkan akan menumbuhkan perasaan kasih sayang dan perhatian. Mereka juga banyak 
menggunakan jejaring sosial sebagai sarana penyebaran virus di dunia maya untuk bertukar informasi tentang kesehatan fisik dan mental mereka dengan publik.

Efektivitas komunikasi dan interaksi antara orang-orang dapat menyebabkan tanggapan negatif dan positif dalam konteks. Disadari atau tidak, komunikasi membantu memotivasi perilaku dan kemampuan untuk mengubah perilaku. Oleh karena itu, dari sudut pandang komunikasi, akurasi, keterampilan, dan kebijaksanaan diperlukan untuk memastikan bahwa motif yang dihasilkan selaras dengan tujuan yang diharapkan. Untuk menciptakan komunikasi yang efektif dan saling memotivasi, lebih baik memiliki kemampuan memberi dan menerima informasi terlebih dahulu, daripada hanya berkeliaran di dunia maya dan memikirkan dampak komunikasi. Diperlukan penelitian lebih lanjut tentang pengaruh komunikasi digital terhadap motivasi. ${ }^{16}$

\section{BAB III \\ PENUTUP}

${ }^{16}$ Basthoumi Muslih, 'Urgensi Komunikasi Dalam Menumbuhkan Motivasi Di Era Pandemi Covid-19', Jurnal Penelitian Manajemen Terapan (PENATARAN), 5.1 (2020), 57-65. 


\section{A. Kesimpulan}

Komunikasi adalah proses penyampaian pesan dari komunikator kepada komunikator dalam berbagai jenis pesan, dan efektif jika digunakan metode penyampaian pesan yang memenuhi syarat atau kemampuan komunikator untuk menerima pesan tersebut. Efek ini dapat dilihat dengan memperhatikan umpan balik yang disampaikan dalam komunikasi.

Komunikasi Islami adalah proses transfer nilai-nilai Islam dari pembawa ke pembawa dengan menggunakan prinsip-prinsip komunikasi yang sesuai dengan AlQur'an dan hadits yang memerintahkan manusia untuk melakukan amar ma'ruf nahi munkar.

Keunggulan komunikasi dalam Islam itu sendiri adalah bahwa keberadaan komunikasi Islam ditujukan secara khusus untuk membimbing umat Islam dan masyarakat biasa untuk berkomunikasi dengan Penciptanya dan dengan diri mereka sendiri dan orang lain sesuai dengan prinsip-prinsip Islam. Komunikasi dengan pemimpin agama akan mengikuti jalan yang telah ditentukan oleh Allah SWT.

\section{B. Saran}

Komunikasi merupakan salah satu aspek dari hubungan interpersonal yang baik. Tanpa komunikasi, sulit untuk menghindari kerentanan interaksi manusia. Oleh karena itu, yang kita butuhkan dalam hidup ini adalah komunikasi. Dan menciptakan komunikasi yang berkualitas sangat penting.

Dalam penyusunan artikel ini, penulis berharap para pembaca khususnya mahasiswa memahami dan memahami makna, manfaat dan urgensi komunikasi. 


\section{DAFTAR PUSTAKA}

Arifin, H. Anwar, Ilmu Komunikasi Sebuah Pengantar Ringkas (Jakarta: Rajawali Press, 1992)

Cangara, Hafied, Pengantar Ilmu Komunikasi (Jakarta: Raja Grafindo Persada, 1998)

— Pengantar Ilmu Komunikasi (Jakarta: PT. Raja Grafindo Persada, 2008)

Effendi, Onong Uchjana, Ilmu Komunikasi Teori Dan Praktek (Bandung: PT. Remaja Rosdakarya, 1990)

Fatimah, S. INFLUENCE OF PSYCHOLOGICAL FACTORS, CULTURAL FACTORS, PERSONAL FACTORS, AND SOCIAL FACTORS ON THE INNOVATION AND STRATEGY STUDENT DECISION.

Hakki, Ahmad Sultra Rustan dan Nurhakki, Pengantar Ilmu Komunikasi, ed. by Deepublish (Yogyakarta, 2017)

Haramain, Muhammad, Prinsip-Prinsip Komunikasi Dalam Al-Qur ' an (Pare-Pare: IAIN Parepare Nusantara Press, 2019)

Hefni, Dr. Harjani, Komunikasi Islam (Jakarta: Kencana, 2015)

Joseph A. Devito, Agus Maulana, Komunikasi Antar Manusia (Jakarta: Karisma Publishing Group, 2011)

Mulyana, Dedy, Mau Kemana Ilmu Komunikasi Kita. Ilmu Komunikasi Sekarang Dan Tantangan Masa Depan (Jakarta: Kencana, 2013)

Muslih, Basthoumi, 'Urgensi Komunikasi Dalam Menumbuhkan Motivasi Di Era Pandemi Covid-19', Jurnal Penelitian Manajemen Terapan (PENATARAN), 5.1 (2020), 57-65

Mustofa, Muhamad Bisri, Siti Wuryan, and Rosidi, 'Urgensi Komunikasi Interpersonal Dalam Al-Qur'an Sebagai Pustakawan', AL-HIKMAH: Media Dakwah, Komunikasi, $\quad$ Sosial Dan Budaya, $11.2 \quad$ (2020), $\quad$ 85-94 <https://doi.org/10.32505/hikmah.v11i2.2544>

Nazarullah, 'Teori-Teori Komunikasi Massa Dalam Perspektif Islam', Peurawi, 1.1 (2018), 1-16

RI, Departemen Pendidikan dan Kebudayaan, Kamus Besar Bahasa Indonesia (Jakarta: Balai Pustaka, 1990) 
Romeltea, 'Komunikasi Islam: Pengertian Dan Prinsip', 1 Juni, 2020 $<$ https://romeltea.com/komunikasi-islam-makna-dan-prinsip/> [accessed 22 December 2021]

Sadily, John M. Echols dan Hasan, Kamus Inggris Indonesia (Jakarta: Gramedia, 1993)

Shihab, M. Quraish, Tafsir Al-Misbah: Pesan Dan Kesan Dalam Al-Quran (Jakarta: Lentera Hati, 2003) 